\title{
Comparative studies on the feeding behavior of two heterotrophic nanoflagellates: the filter- feeding choanoflagellate Monosiga ovata and the raptorial-feeding kinetoplastid Rhynchomonas nasuta
}

\author{
Jens Boenigk* ${ }^{*}$ Hartmut Arndt \\ Department of General Ecology and Limnology, Zoological Institute, University of Cologne, 50923 Cologne, Germany
}

\begin{abstract}
Even though bacterivorous flagellates have been recognized as being able to structure the bacterial community, their behavioral basis for food selection is hardly known. We investigated the feeding behavior of the filter-feeding choanoflagellate Monosiga ovata and the raptorial-feeding kinetoplastid flagellate Rhynchomonas nasuta feeding on a bacterial community dominated by Pseudomonas putida and compared it to that of interception-feeding flagellates. M. ovata handles several food particles simultaneously. In contrast, $R$. nasuta handles only 1 particle at a time. The handling time for 1 prey particle is in the range of $3.7 \mathrm{~s}$ for $R$. nasuta but more than $300 \mathrm{~s}$ for $M$. ovata. The speed of food particles within the feeding current of $M$. ovata was only $9.3 \pm 5.7 \mu \mathrm{m} \mathrm{s}^{-1}$ but due to the large surface of the collar the filtered water volume was $6.4 \mathrm{nl} \mathrm{h}^{-1}$ and therefore comparable to that of interception-feeding flagellates of a similar size. Bacteria ingested by M. ovata were significantly smaller compared to the bacteria in the medium $(p=0.001)$. Size selection of food particles occurs during the processing of food items. This is in contrast to raptorial-feeding $R$. nasuta, which shows passive food size selection for bigger particles during the contact phase. Attachment of bacteria proved to be an efficient protection mechanism, defending them from being grazed by flagellates. There are significant species-specific differences in the processing of food particles which explain the coexistence of various bacterivorous nanoflagellates in the size range of 3 to $5 \mu \mathrm{m}$ and indicate the existence of specific predation pressure on different bacteria.
\end{abstract}

KEY WORDS: Protozoa $\cdot$ Microbial food web $\cdot$ Feeding ecology $\cdot$ Nanoflagellate

\section{INTRODUCTION}

Grazing by heterotrophic nanoflagellates is an important factor in structuring bacterial communities in the field. A significant part of bacterial production is consumed by heterotrophic nanoflagellates (HNF; see Andersen \& Fenchel 1985, Jürgens et al. 1994). Food selectivity by HNF has widely been discussed as being the main factor responsible for bacterial population

*E-mail: jens.boenigk@uni-koeln.de shift (Güde 1979, Andersson et al. 1986). HNF-mediated changes in the culture nutrient conditions and species-specific viral lysis may also change the bacterial spectrum (e.g. Hahn et al. 1999). For a better understanding of the way the microbial food web functions, the responsible underlying mechanisms of food selection have to be determined.

Experiments with surrogates and fluorescently labeled prey allow the investigation of food vacuole content (e.g. Sherr et al. 1987, Landry et al. 1991). These experiments have shown different ingestion and clearance rates for different prey particles offered (e.g. 
González et al. 1990, Monger et al. 1999). However, these experiments do not answer the question of whether selection, i.e. an active process by the predator, or passive mechanisms such as contact probability (caused by prey motility, physicochemical interactions, etc.) are responsible for this observation. The fundamental question as to whether or not heterotrophic nanoflagellates are able to select food particles cannot satisfactorily be answered by feeding experiments. Bacterivorous protozoa have been classified according to their feeding mechanisms as filter feeders on the one hand and interception feeders or raptorial feeders on the other (e.g. Fenchel 1987). For protozoans, the term 'filter feeding' is defined as the production of a feeding current through a filtration structure for sieving the medium for food particles. The terms 'interception feeding' and 'raptorial feeding' are often used synonymously (Fenchel 1987). In this study, we use the term interception feeding for those flagellates which produce a feeding current and directly intercept food particles, and the term raptorial feeding is used for mobile protozoa which actively search for food particles. Several studies tried to predict feeding mechanisms and food selectivity on the basis of theoretical assumptions (e.g. Fenchel 1986a, Shimeta \& Jumars 1991, Shimeta 1993). Even though filter-feeding ciliates have been studied in detail, there are very few detailed investigations of the feeding process of bacterivorous flagellates. In this study we examined the mechanisms of filter-feeding and raptorial-feeding flagellates and compared them with interception-feeding flagellates as described by Boenigk \& Arndt (2000). We used different techniques of video microscopy to observe the feeding patterns of the filter-feeding choanoflagellate Monosiga ovata and the substrate-associated raptorialfeeding kinetoplastid flagellate Rhynchomonas nasuta.

\section{METHODS}

Monosiga ovata and Rhynchomonas nasuta were isolated from a small pond near the Rybinsk Reservoir, Russia, and kindly provided by A. P. Mylnikov. $M$. ovata had a cell volume of $24.5 \pm 9.5 \mu^{3}$ and the collar was $7.0 \pm 1.0 \mu \mathrm{m}$ in length. $R$. nasuta had a cell volume of $18.5 \pm 5.4 \mu^{3}$, and the proboscis was $1.9 \pm 0.3 \mu \mathrm{m}$ in length and $0.6 \pm 0.2 \mu \mathrm{m}$ in width. Simple inorganic culture media containing $0.1 \mathrm{~g} \mathrm{l}^{-1} \mathrm{KNO}_{3}, 0.01 \mathrm{~g} \mathrm{l}^{-1} \mathrm{MgSO}_{4}$ $\times 7 \mathrm{H}_{2} \mathrm{O}, 0.01 \mathrm{~g} \mathrm{l}^{-1} \mathrm{~K}_{2} \mathrm{HPO}_{4} \times 3 \mathrm{H}_{2} \mathrm{O}$ and $0.001 \mathrm{~g} \mathrm{l}^{-1}$ $\mathrm{FeCl}_{3} \times 6 \mathrm{H}_{2} \mathrm{O}$ (Mylnikov pers. comm.) and enriched with a wheat grain were used for the cultivation of the flagellates. The flagellates were fed $24 \mathrm{~h}$ before the experiment started and cultured at $20^{\circ} \mathrm{C}$ under permanent light to adapt to the experimental conditions. In addition to the background bacteria in the flagellate cultures, the flagellates were fed on Pseudomonas putida MM1 (isolated by Christoffersen et al. 1997) during the experiments. The bacteria were grown on nutrient agar and transferred to a liquid batch culture enriched with glucose $\left(1 \mathrm{~g} \mathrm{l}^{-1}\right) 2 \mathrm{~d}$ before the feeding experiments. Bacterial concentration during the experiments was adjusted to $1-2 \times 10^{7}$ bacteria $\mathrm{ml}^{-1}$. The observations were made with flagellates from exponentially growing cultures.

Observations were made according to Boenigk \& Arndt (2000). Briefly, approximately $6 \mathrm{ml}$ of culture medium were transferred to an observation petri dish (see Fig. 1). The flagellates were allowed to resume a normal feeding behavior for $30 \mathrm{~min}$ after transfer. The relatively large water volume allowed observation times of up to several hours without significant changes in the medium, especially without heating. High resolution observations of the feeding process and size measurements were carried out with a Zeiss

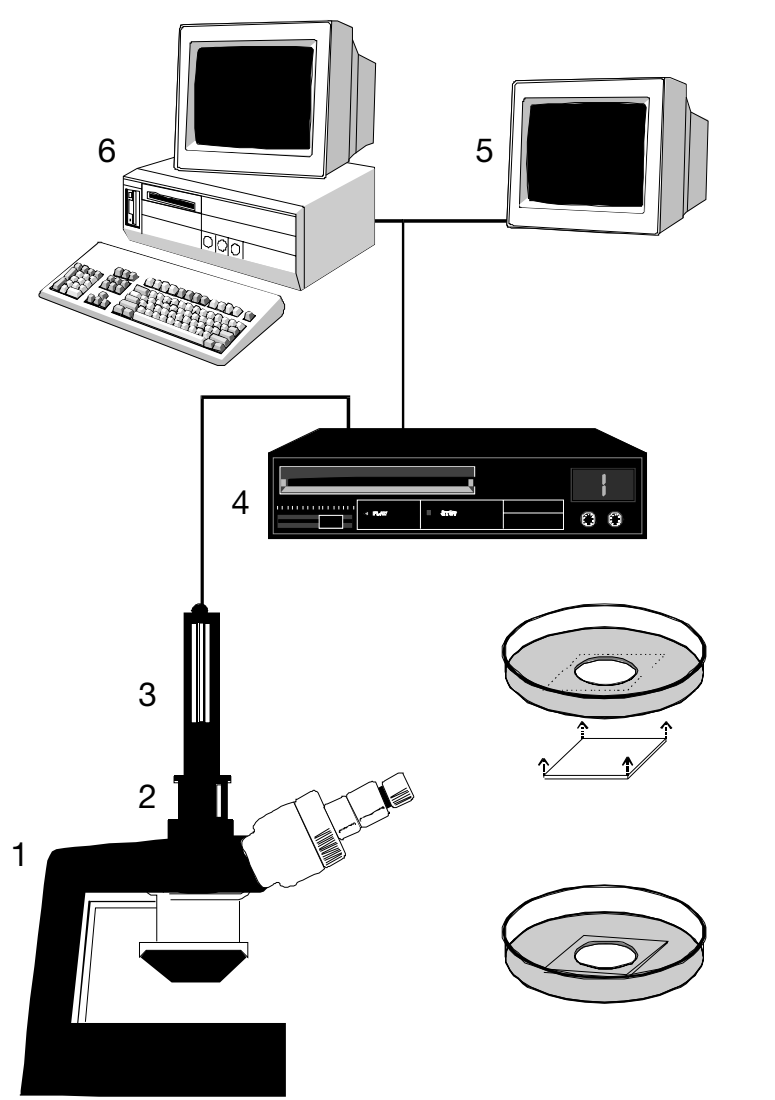

Fig. 1. Experimental design. A petri dish was used as observation chamber for the experiments. A hole $20 \mathrm{~mm}$ in diameter was drilled in the center of the $55 \mathrm{~mm}$ diameter petri dish and a cover slide was attached to the bottom (A, B). The microscope (1) was connected with a zoom adapter (2) to the camera (3). The signal was recorded with an S-VHS recorder (4). Video sequences were analyzed using the monitor (5) and using a computer system (6) 
Axiovert S100 equipped with a Plan Neofluar $100 \times / 1.3$ oil objective. The microscope was connected with a zoom adapter to a MC-1009/S-video camera (AVT Horn, Aalen, Germany). The output of the video camera was fed to an S-VHS recorder (AG 7355, Panasonic; see Fig. 1). Videotape analysis was carried out by using continuous and single-frame play-back. Selected frame series were digitized on a personal computer system using Adobe software (Adobe Premiere and Adobe Photoshop). In addition to a standard $\mathrm{S}-\mathrm{VHS}$ system we tested high resolution video microscopy (CCD camera C4742-95, Hamamatsu) as well as high speed video microscopy (CCD camera C4880-81, Hamamatsu) as a tool for interpreting feeding mechanisms. The high resolution camera and the high speed camera were connected to the compound microscope. The video signal was recorded by a Miro DC 30 video card in a Pentium computer system.

Fifteen individual cells of each species were observed. Size and time measurements were made for each individual cell for at least 1 ingestion and 5 rejections. Length and width of the bacteria were measured using a calibrated video screen. The speed of the bacteria within the feeding current of the flagellates was determined by analysis of successive video frames. The propelled water volume was calculated from observed particle speeds of particles moving parallel to the plane of focus and the surface area of the collar. For this calculation a circular cross-section of the collar was assumed. To analyse the beating frequency of the flagellum, the microscopic lamp of the upright microscope was replaced by a stroboscope (Drelloscop 2008 PHS, Eneberg) that emitted light pulses with a frequency of 2.5 to $416 \mathrm{~Hz}$.

\section{RESULTS}

\section{Feeding of Rhynchomonas nasuta (Kinetoplastida)}

Rhynchomonas nasuta is a typical benthic flagellate. This species is a poor swimmer and mainly creeps along the substratum (see also Swale 1973) at $7.3 \pm$ $2.2 \mu \mathrm{m} \mathrm{s} \mathrm{s}^{-1}(\mathrm{n}=15)$ searching for food particles. Changes in the direction of movement depended on contact with particles. The proboscis beat at a frequency of $9.5 \pm 3.3 \mathrm{~Hz}(\mathrm{n}=20)$ and increased the region in which food particles were searched for. Whenever the proboscis came into contact with a particle, regular beating of the proboscis was interrupted and the particle was handled by the tip of the proboscis. Particles that adhered strongly to the substratum as well as particles that were too big to be ingested were released after $0.9 \pm 2.1 \mathrm{~s}(\mathrm{n}=75)$ and the flagellate resumed its normal searching behavior. Inges- tion of particles occurred at the tip of the proboscis (Fig. 2A). Food particles were taken up by the cytopharynx in the proboscis and food vacuoles were then transported to the posterior end of the cell. Ingestion rate was $12.8 \pm 7.7$ bacteria flagellate ${ }^{-1} h^{-1}(n=15)$. The radius of the movement of the proboscis was about $2.5 \mu \mathrm{m}$, resulting in a maximal area searched of about $7 \times 10^{4} \mu^{2} \mathrm{~h}^{-1}$.

The feeding process was subdivided into 4 feeding phases according to Boenigk \& Arndt (2000): (1) the contact phase - from the first contact between the flagellate and a food particle to a reaction, i.e. stopping the beating of the proboscis $(<0.03 \mathrm{~s}, \mathrm{n}=90)$, (2) the processing phase, i.e. particle handling by the proboscis outside the cell $(0.6 \pm 0.3 \mathrm{~s}, \mathrm{n}=90)$, (3) the ingestion phase sensu stricto, i.e. the transport of the food particle through the proboscis $(0.6 \pm 0.4 \mathrm{~s}, \mathrm{n}=15)$, and (4) the refractory phase - from completed ingestion to

A

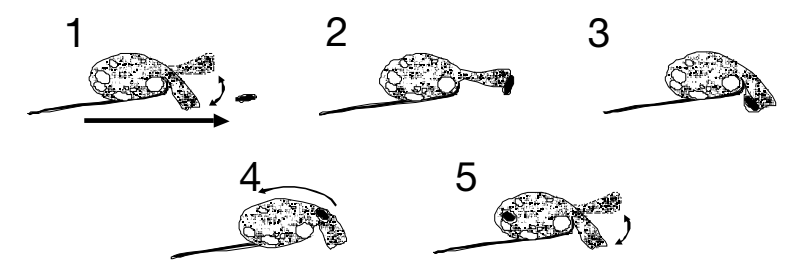

B
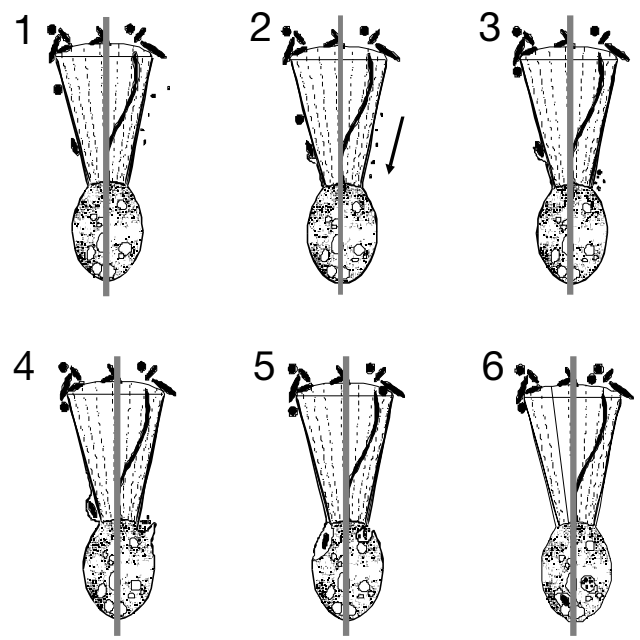

Fig. 2. Feeding behavior of Rhynchomonas nasuta and Monosiga ovata based on video microscopy analysis. (A) $R$. nasuta creeps along the substratum searching for food particles. Particles are handled by the proboscis, ingested and transported to the posterior part of the cell. (B) M. ovata drifts through the medium and produces a feeding current with its flagellum. Food particles are enclosed on the surface of the microvilli by pseudopodia at some distance from the cell body (bigger particles, see left side) or concentrated at the base of the collar and ingested together (smaller particles, see right side) 
renewed normal searching activity $(2.1 \pm 4.2 \mathrm{~s}, \mathrm{n}=15)$. The mean biovolume of bacteria that were in contact with the flagellate $\left(0.29 \pm 0.25 \mu^{3}\right)$ was significantly higher compared to the size spectrum of the bacteria offered $\left(0.13 \pm 0.12 \mu^{3} ;\right.$ ANOVA, $\left.p<0.001\right)$. The ingested bacteria $\left(0.28 \pm 0.23 \mu^{3}\right)$ did not significantly differ in size from the contacted bacteria (ANOVA, $\mathrm{p}=0.819$ ).

\section{Feeding of Monosiga ovata (Choanoflagellida)}

Due to its filter structure, the strain of Monosiga ovata did not swim actively but drifted passively through the medium. In the undisturbed observation chamber the cells sank to the bottom. The flagellum beat at a constant frequency of $14.4 \pm 1.9 \mathrm{~Hz}(\mathrm{n}=20)$ and produced a weak filter current (Fig. 3). The maximal speed of food particles within the feeding current

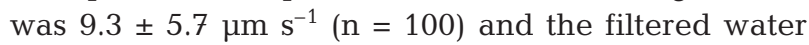
volume was about $6.4 \mathrm{nl} \mathrm{h}^{-1}$. Interruptions of flagellar beating caused by feeding activities were not observed. $M$. ovata handled many particles simultaneously (Fig. 2B, Table 1). Particles were transported along the plasma membranes of the microvilli of the collar in

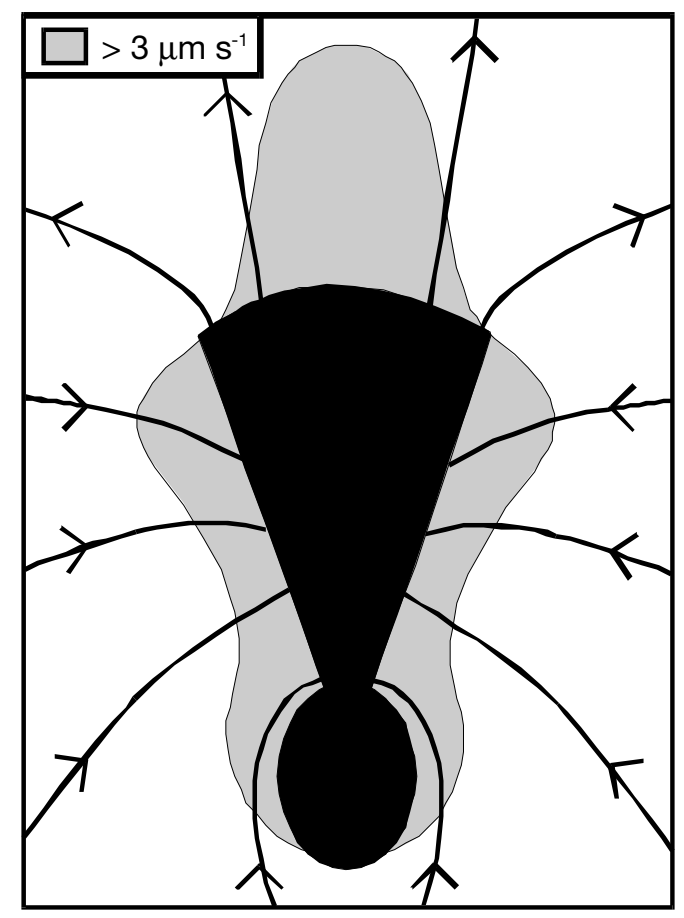

Fig. 3. Feeding current and speed of food particles $\left(\mu \mathrm{m} \mathrm{s} \mathrm{s}^{-1}\right)$ within the feeding current produced by Monosiga ovata. Water passes the filtration structure and food particles are caught in the microvilli both directions at $58 \pm 93 \mathrm{~nm} \mathrm{~s}^{-1}(\mathrm{n}=20)$. Particles which were not ingested were concentrated at the apical region of the collar. Two feeding mechanisms occurred: small particles below about $0.3 \mu \mathrm{m}$ in diameter were transported on the membrane of the collar and concentrated at its base, where they were ingested by the formation of pseudopodia, while bigger particles were enclosed on the surface of the microvilli by pseudopodia at some distance from the cell body (Fig. 2B). The whole food vacuole was transported towards the cell body. After ingestion, food particles were transported towards the posterior part of the cell.

The time budgets of the feeding process could not be determined because, unlike Rhynchomonas nasuta, the flagellate showed no specific reactions. Food particles were handled for several minutes before ingestion. The size of bacteria (biovolume) in contact with the flagellate $\left(0.16 \pm 0.08 \mu^{3}, n=75\right)$ did not differ from the size spectrum of the bacteria in the medium $\left(0.22 \pm 0.10 \mu \mathrm{m}^{3}, \mathrm{n}=100\right.$; ANOVA, $\left.\mathrm{p}=0.402\right)$, but the ingested bacteria were significantly smaller $(0.03 \pm$ $0.05 \mu^{3}, \mathrm{n}=15$; ANOVA, $\left.\mathrm{p}=0.001\right)$. Ingestion occurred outside the collar while excretion occurred inside the collar (Fig. 3). The observed ingestion rate was $24 \pm 5.1$ particles flagellate ${ }^{-1} \mathrm{~h}^{-1}(\mathrm{n}=15)$.

\section{DISCUSSION}

The combination offered by 'normal' analog or digital video techniques $\left(625 \times 400\right.$ pixels, 25 frames $\mathrm{s}^{-1}$, see Fig. 1) was sufficient for most of the applications and was used for the observations. Video microscopy allows detailed observations of protist behavior over long observation periods for a variety of species (e.g. Holen \& Boraas 1991, Boraas et al. 1992, Ishigaki \& Terazaki 1998, Boenigk \& Arndt 2000). However, at present, video microscopy does not allow the observation of fastmoving organisms and the spatial resolution is limited. High-speed and high-resolution video techniques are not yet suitable for observation times of up to several minutes as both have to be recorded by computer systems at a considerable price; thus, recording of long sequences is, so far, limited by the transmission rate from the camera to the computer system and from the main memory of the computer to the hard disk. This may change when computer systems become faster.

In general the data show a high variability within species (expressed as standard deviation). Exponentially growing cultures of flagellates contain smaller cells which are freshly divided as well as bigger cells. This may be the main reason for the considerably high variability in size of prey, ingestion rate and time budget of the feeding phases. Based on a data-set of 87 ingestions and more than 200 captures for Cafeteria roen- 
Table 1. Comparison of the parameters of the feeding behavior of 6 different heterotrophic nanoflagellates studied by video microscopy (data for Bodo saltans, Cafeteria roenbergensis, Spumella sp. and Ochromonas sp. from Boenigk \& Arndt 2000). Particle speed (mean \pm SD) was calculated from observation on 30 individual flagellates. Time budgets (mean \pm SD) were calculated from 87 and 15 ingestions for $C$. roenbergensis and the other flagellates, respectively. Cell volume $(m e a n \pm S D ; n=100)$. $\times$ : yes; $(\times)$ reduced importance

\begin{tabular}{|c|c|c|c|c|c|c|}
\hline & $\begin{array}{l}\text { Monosiga } \\
\text { ovata }\end{array}$ & $\begin{array}{l}\text { Rhynchomonas } \\
\text { nasuta }\end{array}$ & $\begin{array}{l}\text { Bodo } \\
\text { saltans }\end{array}$ & $\begin{array}{l}\text { Cafeteria } \\
\text { roenbergensis }\end{array}$ & $\begin{array}{l}\text { Spumella } \\
\text { sp. }\end{array}$ & $\begin{array}{l}\text { Ochromonas } \\
\text { sp. }\end{array}$ \\
\hline \multicolumn{7}{|l|}{ Feeding type } \\
\hline Cell volume $\left(\mu \mathrm{m}^{3}\right)$ & $24.5 \pm 9.5$ & $18.5 \pm 5.4$ & $25.8 \pm 7.7$ & $18.5 \pm 12.7$ & $75.4 \pm 40.6$ & $163 \pm 76$ \\
\hline Filter feeder & $\times$ & & & & & \\
\hline Raptorial feeder & & $\times$ & & & & \\
\hline Interception feeder & & & $\times$ & $x$ & $\times$ & $\times$ \\
\hline \multicolumn{7}{|l|}{ Particle handling } \\
\hline Simultanously handled particles & Many & 1 & 1 & 1 & 1 & 1 \\
\hline $\begin{array}{l}\text { Mean biovolume of ingested bacteria/ } \\
\text { mean biovolume of offered bacteria }\end{array}$ & 0.14 & 2.33 & 2.15 & 0.80 & 1.08 & 1.95 \\
\hline Accumulation before ingestion & $\times$ & & & & & \\
\hline Ingestion of single particles & $(\times)$ & $\times$ & $\times$ & $\times$ & $\times$ & $\times$ \\
\hline \multicolumn{7}{|l|}{ Prey } \\
\hline Attached bacteria & & $x$ & & & & \\
\hline Suspended bacteria & $\times$ & $(\times)$ & $\times$ & $\times$ & $x$ & $\times$ \\
\hline \multicolumn{7}{|l|}{ Prey capture } \\
\hline $\begin{array}{l}\text { Particle speed in the } \\
\text { 'filter current' }\left(\mu \mathrm{m} \mathrm{s}^{-1}\right)\end{array}$ & $9 \pm 6$ & & $91 \pm 30$ & $105 \pm 23$ & $50 \pm 27$ & $112 \pm 38$ \\
\hline Maximal theoretical clearance $\left(\mu \mathrm{m}^{3} \mathrm{~h}^{-1}\right)$ & 6.4 & & 4.1 & 6.0 & 5.3 & 14.7 \\
\hline $\begin{array}{l}\text { Volume-specific maximal theoretical } \\
\text { clearance }\left(10^{5} \text { units cell volume } \mathrm{h}^{-1}\right)\end{array}$ & 1.5 & & 1.6 & 3.3 & 0.8 & 0.8 \\
\hline $\begin{array}{l}\text { Flagellate attached to the substratum } \\
\text { during ingestion }\end{array}$ & $\times$ & $\times$ & $\times$ & $x$ & $\times$ & $\times$ \\
\hline $\begin{array}{l}\text { Flagellate swimming/suspended } \\
\text { during ingestion }\end{array}$ & $\times$ & & & & $\times$ & $\times$ \\
\hline \multicolumn{7}{|l|}{ Ingestion process } \\
\hline Prey enclosed by pseudopodia & $\times$ & & & & $x$ & $\times$ \\
\hline Prey ingested through cytopharynx & & $x$ & $x$ & & & \\
\hline $\begin{array}{l}\text { Prey ingested by an invagination } \\
\text { of the cell surface }\end{array}$ & & & & $\times$ & & \\
\hline \multicolumn{7}{|l|}{ Time budget (s) } \\
\hline 'Handling time' & $>300$ & $3.7 \pm 4.5$ & $33 \pm 52$ & $95 \pm 64$ & $10 \pm 5.8$ & $3.8 \pm 2.0$ \\
\hline Contact time & & $0.03 \pm 0.04$ & $0.05 \pm 0.4$ & $0.27 \pm 0.26$ & $0.07 \pm 0.03$ & $0.04 \pm 0.01$ \\
\hline Processing time & $\sim 300$ & $0.6 \pm 0.5$ & $3.1 \pm 1.0$ & $7.6 \pm 5.9$ & $4.1 \pm 3.1$ & $0.1 \pm 0.8$ \\
\hline Ingestion time & $>20$ & $0.6 \pm 0.4$ & $1.9 \pm 0.4$ & $6.1 \pm 3.8$ & $1.7 \pm 1.2$ & $0.7 \pm 0.3$ \\
\hline Refractory time & & $2.1 \pm 4.3$ & $28.1 \pm 52.2$ & $82.3 \pm 63.1$ & $4.5 \pm 4.3$ & $2.2 \pm 1.7$ \\
\hline
\end{tabular}

bergensis, Boenigk \& Arndt (2000) reported that variability was hardly less than that reported for other flagellates based on 15 ingestions only. It seems to be hard to reduce variability any further by increasing the number of investigations since variability is mainly due to a high individual variability within the cultures. However, at least 10 to 12 individual cells must be observed to obtain reliable results (authors' pers. obs.). The mean as well as the standard deviation then seem to be reliable measures for species characteristics.

Although bacteria are a main food source for heterotrophic nanoflagellates (Andersen \& Fenchel 1985, Jürgens et al. 1994, Arndt et al. 2000), the mechanisms used to capture and ingest bacteria differ strongly between species. For example, the feeding current of
Monosiga ovata is much weaker compared to that created by interception-feeding flagellates (Fenchel 1987, Boenigk \& Arndt 2000; see Table 1). However, the specific clearance is similar to that of chrysomonads due to the large filtration structure (Fenchel 1982; see Table 1). The long handling times in comparison to other flagellates are compensated by simultaneous handling of many food particles and by accumulation of food particles (especially particles smaller than about $0.3 \mu \mathrm{m}$ ) at the cell surface outside the collar before their ingestion (see also Leadbeater \& Morton 1974).

Due to these differences in feeding strategies, protozoa often are classified according to their feeding mechanisms, for example, into filter feeders, raptorial feeders and interception feeders (Fenchel 1987). Clas- 
sifications of feeding mechanisms are limited due to the variability among protozoa. For example, Monosiga ovata, a choanoflagellate and therefore classified as a typical filter-feeding flagellate (Fenchel 1987), was found to produce a filter current of a maximal current velocity of about $10 \mu \mathrm{m} \mathrm{s}^{-1}$ only. Therefore external water currents and diffusion seem to play an important role for food capture, as is characteristic for diffusion-feeding flagellates. In contrast, the feeding behavior of Cafeteria roenbergensis, Spumella sp., Ochromonas sp. and Bodo saltans (Boenigk \& Arndt 2000) on the one hand and Rhynchomonas nasuta on the other, all raptorial feeders in the sense of Fenchel (1987), differs significantly. Therefore this group was split up into interception feeders and raptorial feeders in this investigation. In another study (Boenigk \& Arndt 2000), we showed that the differences even between flagellate species of the same feeding type and of a similar size are significant. Thus, even though rough classifications allow general features of the feeding behavior to be described, they seem to be no appropriate basis for the investigation of the feeding ecology of flagellates as the high variability between species cannot be taken into account.

Food selection has been reported with respect to size, surface properties of the bacteria or motility of the prey (e.g. Jürgens \& DeMott 1995, Monger et al. 1999). Theoretical considerations predict that passive mechanisms such as particle-specific contact probabilities are responsible for food size selection (Shimeta \& Jumars 1991). We could support these assumptions regarding the interception-feeding (Boenigk \& Arndt 2000) and raptorial-feeding flagellates (this study). In contrast, passive food-size selection should not occur in filterfeeding flagellates (cf. Fenchel 1987). However, a strong food-size selection was observed during particle handling in our experiment, but it could not be determined whether or not this size selection was an active process on the part of the flagellate or if it is driven by passive forces.

Due to the various selection and feeding mechanisms the different flagellate species are obviously adapted to diverse food spectra. Besides attachment of bacteria, size selection was especially in the focus of the investigation (Table 1). Species-specific differences in food selection cause a strongly species-specific grazing pressure on bacteria. Ochromonas sp., Bodo saltans and Rhynchomonas nasuta feed on large bacteria, whereas Spumella sp. and Cafeteria roenbergensis feed on intermediate bacteria and Monosiga ovata feeds exclusively on small bacteria. This agrees with findings that choanoflagellates are typical of pelagic waters with considerably smaller sized bacteria due to metazoan grazing (Arndt et al. 2000). The flagellates may be omnivores but due to their size bac- teria seem to be the main diet. Depending on the mobility of substrate-associated raptorial flagellates, these species feed mainly on attached bacteria (see also Fenchel 1986b, Caron 1987). We also observed that $R$. nasuta is able to feed on particles drifting along the substratum at a distance of up to about $2-3 \mu \mathrm{m}$ to the surface of the substrate (authors' pers. obs.). This is in contrast to the interception- and filter-feeding flagellates, which feed exclusively on suspended bacteria. Other factors such as surface hydrophobicity (Monger et al. 1999) have also been reported to be responsible for species-specific differences in the grazing pressure. The observed differences in the handling time may be adaptations to different food concentrations and to environmental conditions. Due to the short handling times of $R$. nasuta or Ochromonas sp. these flagellates are able to handle many particles within a short time. This may be advantageous in an environment containing a high concentration of food particles. Therefore short handling times may be advantageous when bacterial abundance is high. Especially microhabitats such as flocks, e.g. lake snow (Grossart \& Simon 1993), or benthic habitats are rich in edible (e.g. bacteria) as well as inedible (e.g. clay) particles, respectively. Short handling times may therefore be characteristic of substrate-associated flagellates such as $R$. nasuta. Due to species-specific differences in feeding behavior it seems questionable whether the calculation of the flagellates' grazing pressure on bacteria as calculated in various studies (e.g. KuuppoLeinikki 1990, Berninger et al. 1991) is a suitable measure for the comparison of different food webs. Depending on the species composition of HNF in the field, some bacteria may be strongly grazed whereas others may hardly be affected. Our results imply that species-based investigations of protists and bacteria will be necessary to understand microbial food web dynamics in the field.

Acknowledgements. The authors wish to thank Barry S. C. Leadbeater and Alexander P. Mylnikov for helpful discussions, Fred Bartlett for linguistic corrections of the manuscript, Brigitte Grafe for keeping the culture strain collection and 3 anonymous reviewers for constructive critcism. The Deutsche Forschungsgemeinschaft is acknowledged for financial support (Ar 288/3-1).

\section{LITERATURE CITED}

Andersen P, Fenchel $T$ (1985) Bacterivory by microheterotrophic flagellates in seawater samples. Limnol Oceanogr 30:198-202

Andersson A, Larsson U, Hagström Å (1986) Size-selective grazing by a microflagellate on pelagic bacteria. Mar Ecol Prog Ser 33:51-57

Arndt H, Dietrich D, Auer B, Cleven EJ, Gräfenhan T, Weitere M, Mylnikov AP (2000) Functional diversity of heterotro- 
phic flagellates in aquatic ecosystems. In: Leadbeater BSC, Green JC (eds) The flagellates. Taylor \& Francis, London, p 240-268

Berninger UG, Finlay BJ, Kuuppo-Leinikki P (1991) Protozoan control of bacterial abundance in freshwater. Limnol Oceanogr 36:139-147

Boenigk J, Arndt H (2000) Particle handling during interception-feeding by four species of heterotrophic nanoflagellates. J Eukaryot Microbiol 47:350-358

Boraas ME, Seale DB, Holen D (1992) Predatory behaviour of Ochromonas analyzed with video microscopy. Arch Hydrobiol 123:459-468

Caron DA (1987) Grazing of attached bacteria by heterotrophic microflagellates. Microb Ecol 13:203-218

Christoffersen K, Nybroe O, Jürgens K, Hansen M (1997) Measurement of bacterivory by heterotrophic nanoflagellates using immunofluorescence labeling of ingested cells. Aquat Microb Ecol 13:127-134

Fenchel T (1982) Ecology of heterotrophic microflagellates. II. Bioenergetics and growth. Mar Ecol Prog Ser 8:225-231

Fenchel T (1986a) Protozoan filter-feeding. Prog Protistol 1: 65-113

Fenchel T (1986b) Ecology of heterotrophic microflagellates. Adv Microb Ecol 9:57-97

Fenchel T (1987) Ecology of Protozoa. The biology of freeliving phagotrophic protists. Science Tech. Publishers, Madison, WI, p 32-52

González JM, Sherr EB, Sherr BF (1990) Size-selective grazing on bacteria by natural assemblages of estuarine flagellates and ciliates. Appl Environ Microbiol 56:583-589

Grossart HP, Simon M (1993) Limnetic macroscopic organic aggregates (lake snow): occurrence, characteristics, and microbial dynamics in Lake Constance. Limnol Oceanogr 38:532-546

Güde H (1979) Grazing by Protozoa as selection factor for activated sludge bacteria. Microb Ecol 5:225-237

Hahn MW, Moore ERB, Höfle MG (1999) Bacterial filament formation, a defense mechanism against flagellate grazing, is growth rate controlled in bacteria of different phyla. Appl Environ Microbiol 65:25-35

Editorial responsibility: Karel Šimek, České Budějovice, Czech Republic
Holen DA, Boraas ME (1991) The feeding behaviour of Spumella sp. as a function of particle size: implications for bacerial size in pelagic systems. Oecologia 220:73-88

Ishigaki T, Terazaki M (1998) Grazing behaviour of heterotrophic nanoflagellates observed with a high speed VTR system. J Eukaryot Microbiol 45:484-487

Jürgens K, DeMott WR (1995) Behavioral flexibility in prey selection by bacterivorous nanoflagellates. Limnol Oceanogr 40:1503-1507

Jürgens K, Arndt H, Rothaupt KO (1994) Zooplankton-mediated changes of bacterial community structure. Microb Ecol 27:27-42

Kuupo-Leinikki P (1990) Protozoan grazing on planktonic bacteria and its impact on bacterial population. Mar Ecol Prog Ser 63:227-238

Landry MR, Lehner-Fournier JM, Sundstrom JA, Fagerness VL, Selph KE (1991) Discrimination between living und heat-killed prey by a marine zooflagellate, Paraphysomonas vestita (Stokes). J Exp Mar Biol Ecol 146: $139-151$

Leadbeater BSC, Morton C (1974) A microscopical study of a marine species of Codosiga James-Clark (Choanoflagellata) with special reference to the ingestion of bacteria. Biol J Linn Soc 6:337-347

Monger BC, Landry MR, Brown SL (1999) Feeding selection of heterotrophic marine nanoflagellates based on the surface hydrophobicity of their planktonic prey. Limnol Oceanogr 44:1917-1927

Sherr BF, Sherr EB, Fallon RD (1987) Use of monodispersed, fluorescently labeled bacteria to estimate in situ protozoan bacterivory. Appl Environ Microbiol 53:958-965

Shimeta J (1993) Diffusional encounter of submicrometer particles and small cells by suspension feeders. Limnol Oceanogr 38:456-465

Shimeta J, Jumars PA (1991) Physical mechanisms and rates of particle capture by suspension feeders. Oceanogr Mar Biol Annu Rev 29:191-257

Swale EMF (1973) A study of the colourless flagellate Rhynchomonas nasuta (Stokes) Klebs. Biol J Linn Soc 5: $255-264$

Submitted: June 27, 2000; Accepted: August 30, 2000

Proofs received from author(s): October 2, 2000 
